Helgoländer wiss. Meeresunters. 24, 163-173 (1973)

\title{
Orientation in the sea fan Eunicella cavolinii related to water movement
}

\author{
B. VELIMIROV \\ I. Zoologisches Institut der Universität Wien, Lebrkanzel für Meeresbiologie; \\ Wien, Austria
}

KURZFASSUNG: Orientierung der Gorgonarie Eunicella cavolinii zur Wasserbewegung. Die Orientierung der Fächer von Eunicella cavolinii an homogenen (unzerklüfteten) und heterogenen (zerklüfteten) Steilwänden sowie in einem Tunnelsystem wurde quantitativ erfaßt und statistisch ausgewertet. Die Fächerorientierungen wurden mit dem schwingenden bzw. streichenden Wasserkörper korrelliert. Dominierende Wasserbewegungen wurden mit Natriumfluoreszin sichtbar gemacht; ihre Wirkungsbereiche werden stark von der Struktur des Substrats beeinflußt. Die „zweite kritische Tiefe" (oder Zone) wurde durch Fächerprojektionen der Gorgonienaufsichten exfaßt. Für die "zweite kritische Tiefe" wurden typische Standortsmodifikationen charakterisiert, die Wirbelbereiche und starke Turbulenzen beim Zusammenfließen zweier verschiedener Wasserbewegungen anzeigen. Strömungsorientiertes Wachstum von E. cavolinii wurde durch In-situ-Experimente nachgewiesen. Die Fächer rechtwinklig beströmter Kolonien verschiedener Größe wurden mittels allseitig verdrehbarer PVC-Gelenke parallel angeströmt. Nach einem Jahr konnten bei fast allen Kolonien neugerichtetes Wachstum sowie Ausgleichsreaktionen der Aste auf die neuen Strömungsbedingungen festgestellt werden. Das Wachstum der neu orientierten Kolonien wurde mit dem Wachstum ungestörter Kolonien gleicher Größe verglichen; es war in fast allen Fällen weitaus geringer. Die Reorientierung von E. cavolinii wird diskutiert; ähnliche Reaktionen werden bei anderen Sedentariern aufgezeigt.

\section{INTRODUCTION}

Eunicella cavolinii of the family Plexauridae is, together with E. stricta, one of the most abundant gorgonians of the Mediterranean Sea. In living colonies attached to the substratum, regularities in distribution and orientation of branching planes can be observed. PEREs \& PrCARD (1949) studied populations in caves. They point out that Eunicella species adjust their growth pattern to the predominating water movement, but they do not go into details. ABEL (1959) points out that gorgonians depend on light and water movement, and RIEDL $(1964,1971)$ uses this peculiarity for a classification of the littoral. Theodor (1963) and Theodor \& Denizot (1965) observed these phenomena and conclude that gorgonians, as well as some algae, orientate their planes of branching at right angles to prevailing water currents. WAINWRIGHT \& DILLON (1969) used turnable models of sea fans to establish the most stable position for such a shape from a mechanical point of view. From own observations and literature information 
the questions arise: is it possible to use the orientation of the plane of branching of gorgonians to assess prevailing water movements in different biotopes, and can growth orientation be checked experimentally in situ? It is necessary to study typical growth patterns before such an experiment can be set up because hardly anything is known on growth rates of Eunicella species, nor on gorgonians as a whole. The results of this growth study will be presented in a separate paper. Some data, however, will be used here for comparison.

\section{METHODS}

For measurements of orientation of the planes of branching, a clinometer $16 \mathrm{~cm}$ in diameter), equipped with a plumb-line was used and values recorded immediately on a plastic sheet. If a colony had two planes of orientation, both planes were considered. For measurements in caves a compass was used and the values of declination of the planes from the cave entrance were measured. The faces of the cave entrance are positioned 90 degrees to the direction of the water movement; on a compass held horizontally against the planes of the gorgonians, every declination can be observed.

To expose colonies of Eunicella cavolinit to different directions of water movement, they were mounted rigidly on a joint, movable in all directions, and fixed by climb hooks in rock fissures. Colony growth was measured by sliding rule callipers, and the length of every colony part considered. All gorgonians were drawn and photographed to avoid mistakes in measurements and mixing up of the colonies.

To determine the direction of water movement and variations in different parts of the biotope, experiments were made using fluorescein sodium. For general studies the dye was put into a plastic bag equipped with a styrofoam float, anchored to the ground and subsequently punctured. For detailed studies the dye was released into the water at the place of special interest by a diver while the other diver photographed the situation.

Water-movement velocities were measured with a current meter based on the principle of the "Fligelradanemometer" which could easily be handled by the diver. The in situ studies were carried out on the island of Filicudi, northwest of Sicily (Italy).

\section{RESULTS}

\section{Field observations on fan orientation}

The orientation of the colonies of Eunicella cavolinii was measured at three locations, differing in topography and water movement: (1) a steep smooth wall beginning in $8 \mathrm{~m}$ depth and extending down to $15 \mathrm{~m}$, (2) a steep wall beginning in $7 \mathrm{~m}$ and reaching down to $15 \mathrm{~m}$ with a rugged surface cut by a vertical fissure, (3) a submarine tunnel.

* In the original description (Kocs 1887) the species was called Eunicella cavolini. However, according to the international rules of nomenclature, the correct form should be E. cavolinii, since the species was named after CAvolint. 


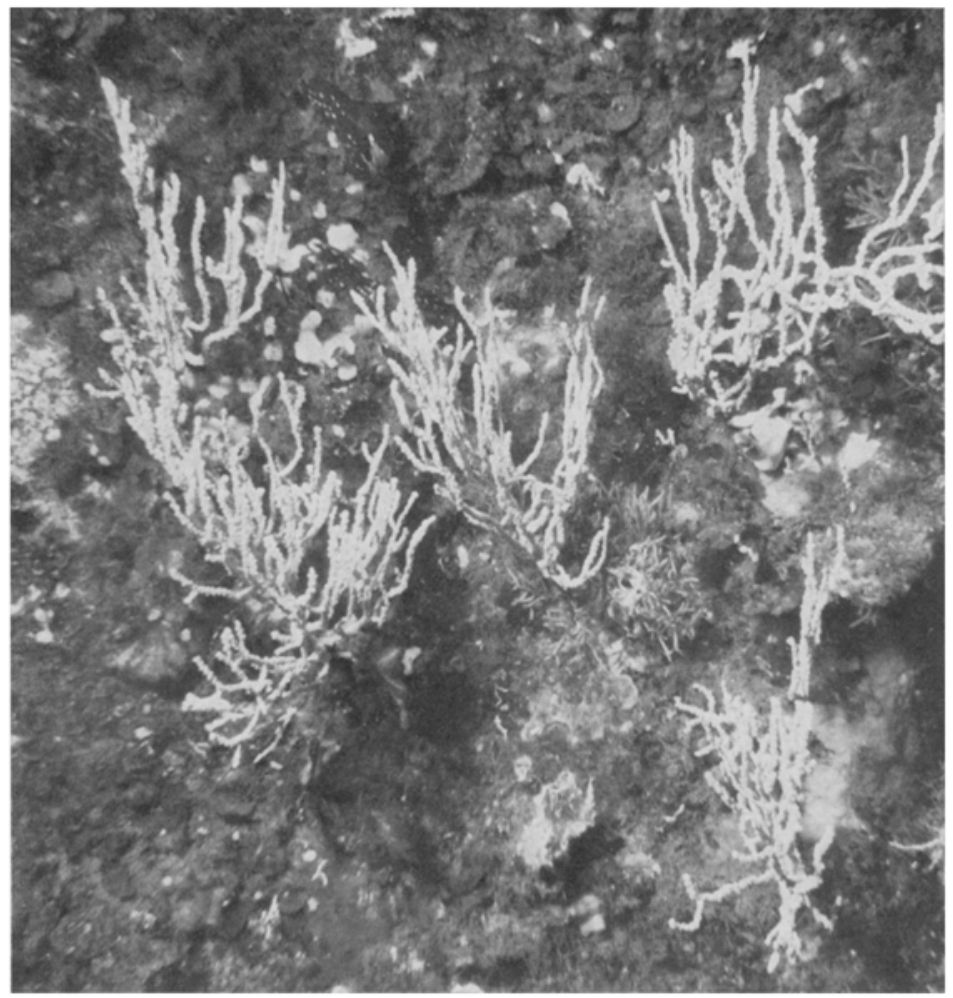

Fig. 1: Eunicella cavolinii colonies with two or more planes of orientation

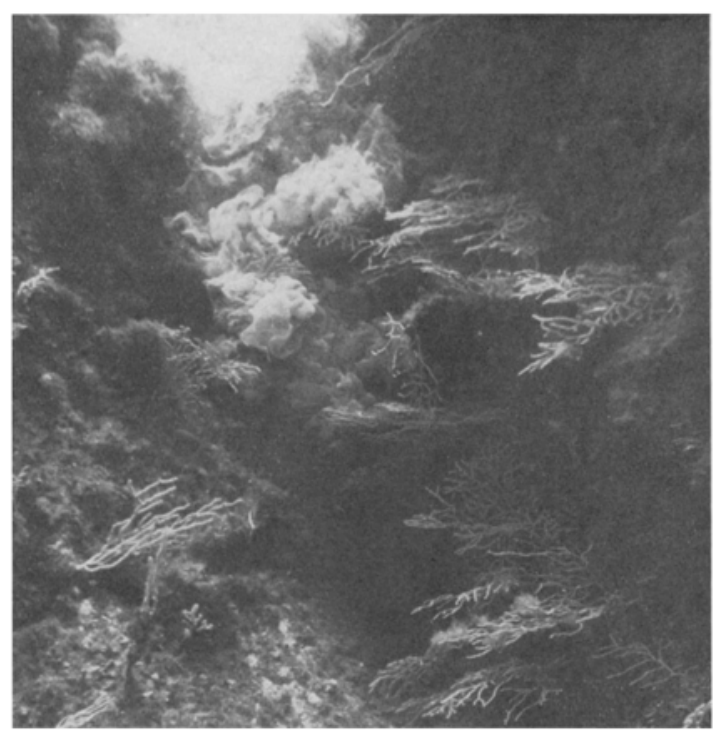

Fig. 2: Fissure in a steep undersea wall. Oscillation movement of waves is revealed by fluorescein colouration 


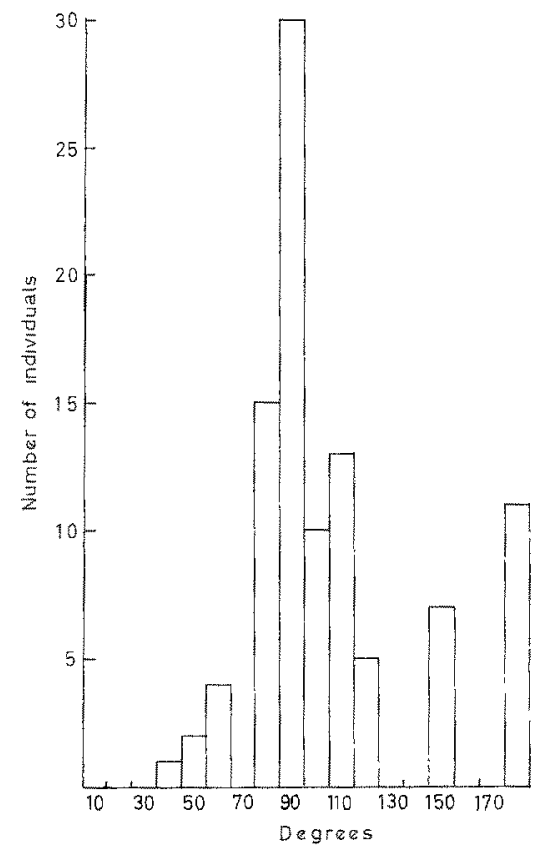

Fig. 3: Eunicella cavolinii. Histogram of orientation frequency of branching planes on a steep smooth undersea wall $(n=99)$

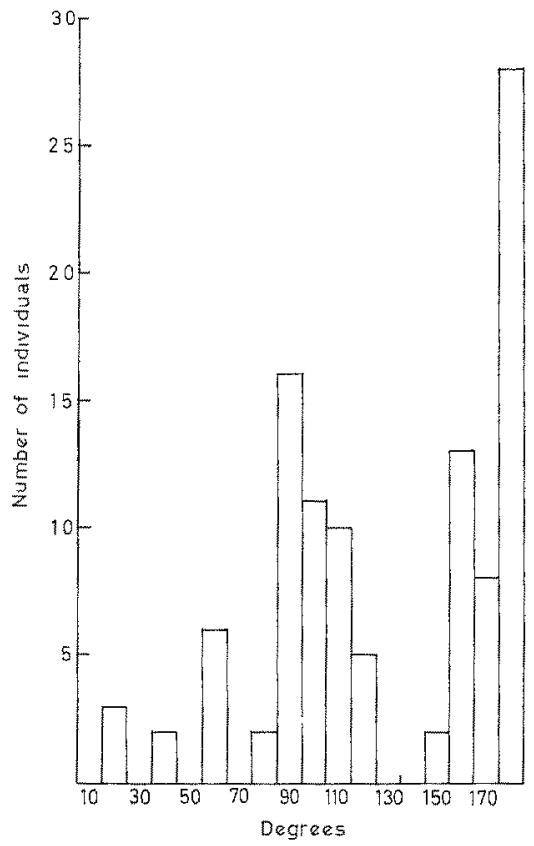

Fig. 4: Eunicella cawoliniz. Histogram of orientation frequency of branching planes on a steep wall with a vertical fissure $(n=106)$

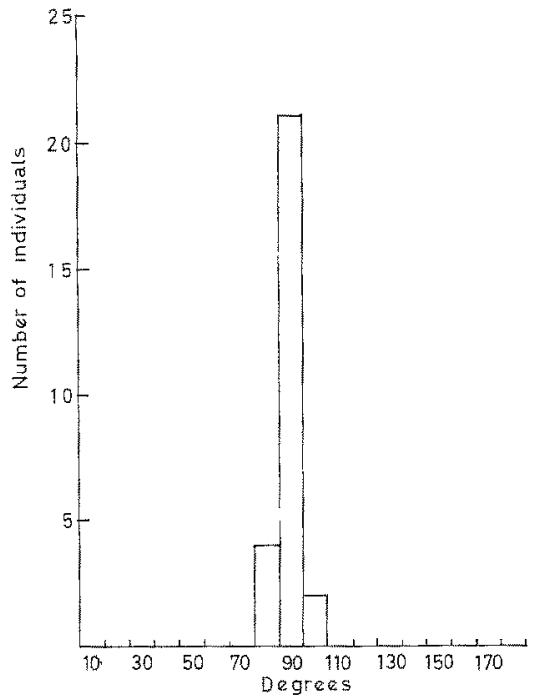

Fig. 5: Eunicella cavalinii. Histogram of orientation frequency of branching planes in a submarine tunnel $(n=26)$ 
Assuming a uniform population density over the whole study area, histograms of fan orientation frequency are used to indicate the number and importance of different water-movement regimes. At location (1), $69 \%$ of the fans were orientated at angles of 80-110 degrees to the horizontal line, 13\% at angles of 150-180 degrees (Fig. 3). Measurements and observations of water movement directions reveal an influence of vertical oscillations due to wave action only in depths between 8 and $9 \mathrm{~m}$. This is the center of distribution of horizontally orientated colonies. The major part of the wall is exposed to predominantly horizontal water flow due to passing currents which mask the slight oscillating effect of the orbital movement at this depth. Between these two levels are most of the colonies which account for the other angles of orientation observed $(12 \%)$, corresponding to the "second critical depth" (RIEDL 1964, 1971). The colonies with two or more planes of orientation (Fig. 1) also occur in this zone. However, one or more of the planes recognized in these fans frequently belong to the two predominant orientations.

Although location (2) has almost the same position with regard to depth, fans orientated 150-180 degrees dominate (49\%) whereas compared to location (1) there are considerably fewer 80-110 degree orientated colonies (Fig. 4).

The fans in the fissure are mainly responsible for this distribution pattern, since the influence of the orbital movements extends considerably further down, causing the fans to orientate horizontally (Fig. 2). Also the second critical depth lies deeper in the vicinity of the fissure.

In location (3) only one orientation type is represented. The special shape of the underwater tunnel permits only water movement parallel to its main axis (Fig, 5).

The frequency distribution of fan orientation in all three locations was tested for regularity by chi square test with 17 degrees of freedom. The differences in $\mathrm{X}^{2}$ values found are significant at the 99 percent level (Table 1).

Table 1

Eunicella cavolinii: Statistical results of frequency distribution in fan orientation

\begin{tabular}{|ccc|}
\hline Location & $\mathrm{X}^{2}$ values & Critical level \\
\hline$(1)$ & 156.10 & 40.75 \\
$(2)$ & 156.90 & 40.75 \\
$(3)$ & 257.97 & 40.75 \\
\hline
\end{tabular}

Fans smaller than $5 \mathrm{~cm}$ total length were not measured. However, most of them showed distinct water-movement related orientation.

\section{The second critical depth}

As mentioned above, the second critical depth is where two types of water movement are alternately effective; it is characterised not only by a predominance of randomly orientated fans but also by characteristic growth-forms having more than one plane of orientation (Fig. 1). Thus, viewed in direction of the main axis, colonies 
can be circumscribed by polygons of different areas (Fig. 6). This method was used to determine the range of the second critical depth after having established the presence of two different water bodies with the help of frequency analysis of orientation. In a

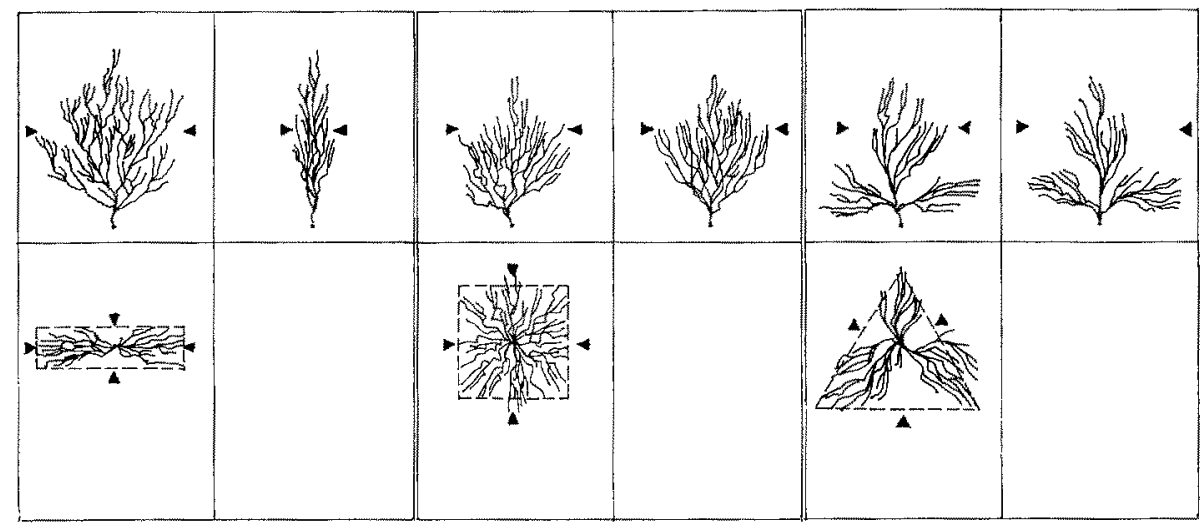

Fig. 6: Eunicella cavolinii. Different growth forms showing circumscription by square, rectangle and triangle

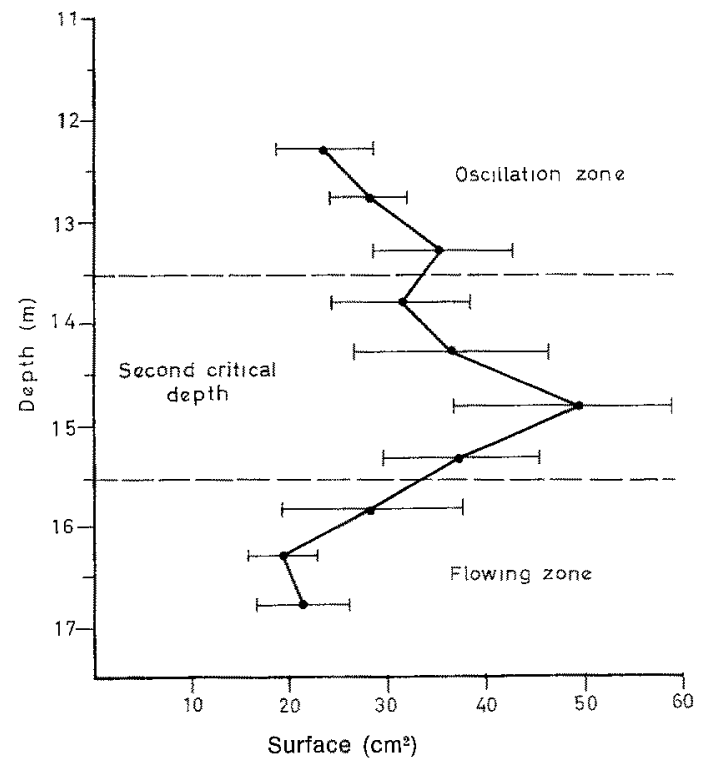

Fig. 7: Eunicella cavolinii. Projected surfaces of fans, seen in the direction of the main axis, plotted against water depth $(m)$ showing three different zones of water movement

transect of $3 \mathrm{~m}$ width on a smooth wall, as in location (1), the projected area of the fans was determined in the above-described manner at $0.5 \mathrm{~m}$ intervals. For the sake of simplicity, the projected area of all fans was approximated by rectangles, squares or triangles. This area was either determined in the field or, in more complicated cases, 
the fan was removed and measured on land. The mean for each zone was plotted against depth. A characteristic peak was found in the zone of maximum disorientation of fans, thus indicating the precise position of the second critical depth (Fig. 7). In addition, the variability in projected area in this zone is much greater than in the zones above and below, which is indicated by the standard deviations.

\section{Experiments}

To test the effect of water movement on the growth and orientation of the fans, underwater experiments were carried out. Eighteen colonies of various size, from 6 to $70 \mathrm{~cm}$ total length, in a depth of 15 to $20 \mathrm{~m}$ were used. The fans were turned from
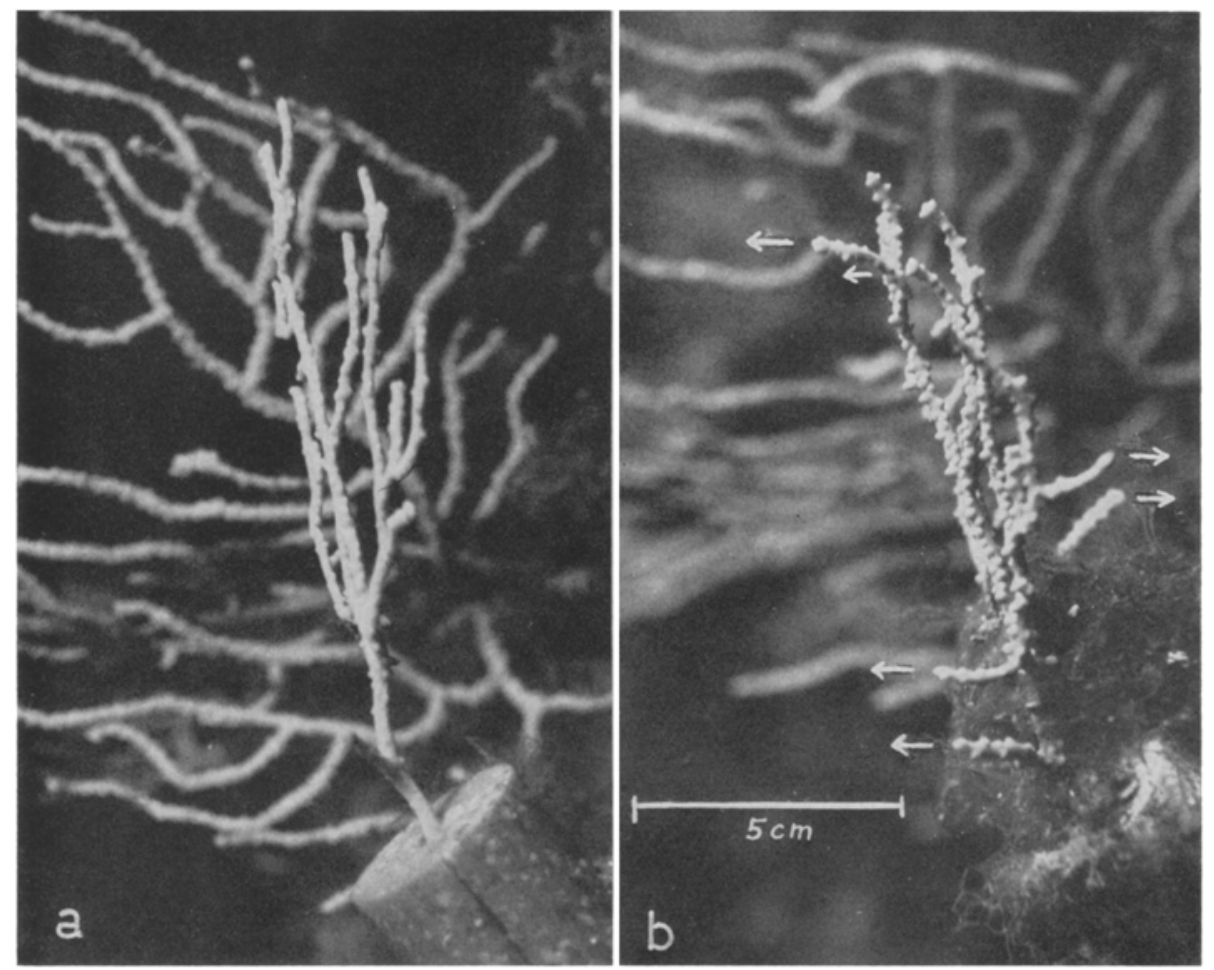

Fig. 8: Eunicella cavolinii. Original growth and reorientation of colony. Sideview a At beginning of experiment; $b$ at end of experiment

their natural position perpendicular to the direction of water movement, until the fan was parallel to this direction. Amount and direction of growth was measured after a period of up to 17 months. Only 10 fans survived the entire experiment, 8 were lost during bad weather. Growth was inhibited in all cases for the first 5 months. This might well have been due to reduced feeding efficiency. After about 5 months growth 

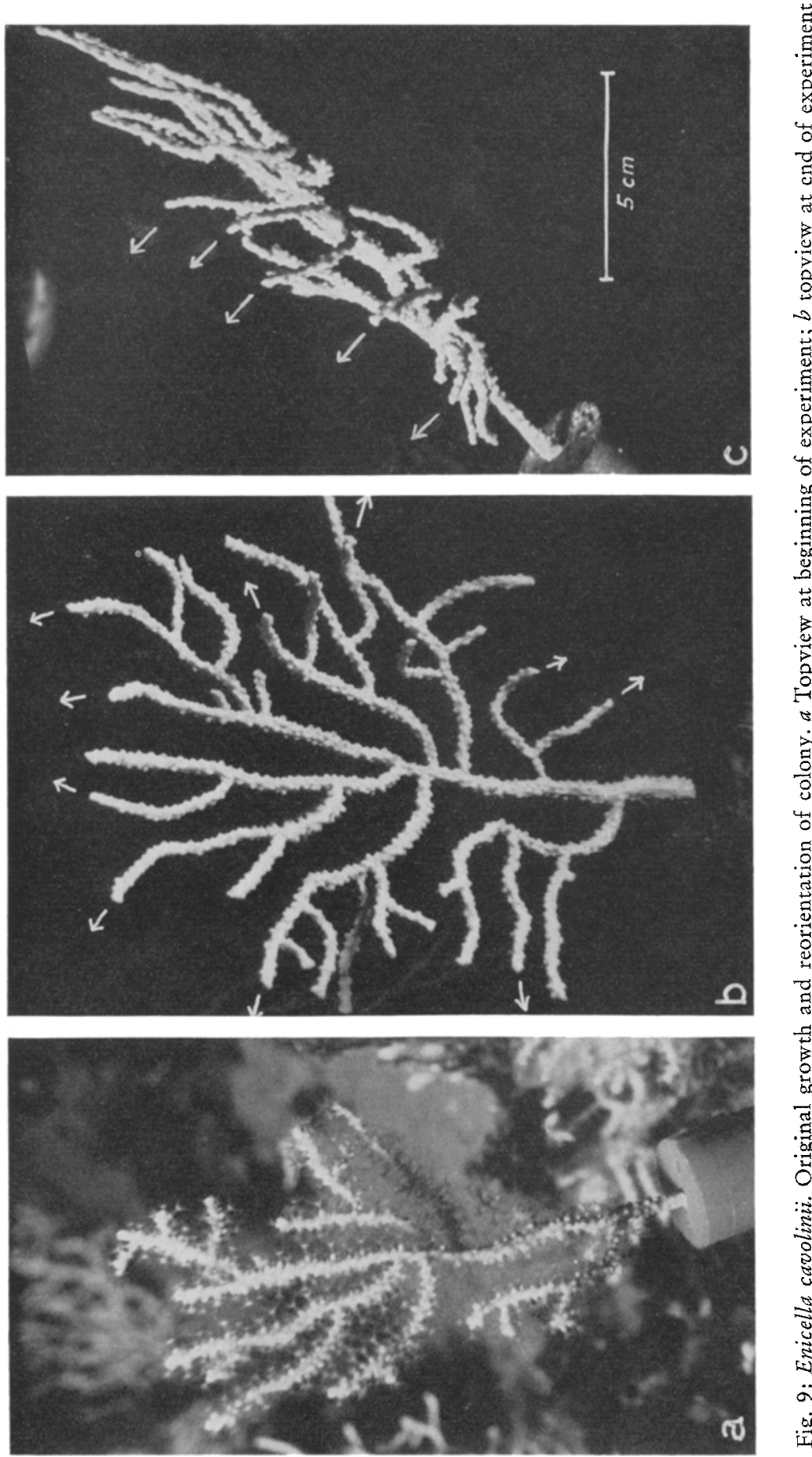
started again. The direction of newly grown fans was perpendicular to the original plane of the fan. New growth started with a curving of the tip of the branch. Branches whose tips grow in the new direction show compensating bends in their older parts to adjust to the new stress.

Some colonies which showed no new growth at all for more than 5 months began to lose their two-dimensional shape, due to branches beginning to project from the main plane of orientation. When new growth finally started, it was again perpendicular to the original fan plane (Figs 8 and 9).

No torsion in the main axis of the stem occurred. Due to the elasticity of the branches, currents cause only slight twisting moments on the fans blade.

Table 2

Comparison of percentage growth from experimental fans and undisturbed colonies. $N_{1}$ : Initial size in $\mathrm{cm}$ (total length), experiment began August, 1971; $\mathrm{N}_{2}$ : Size at the end of the experiment August, 1972; *Initial size, experiment began February 1971

\begin{tabular}{|ccccc|}
\hline $\begin{array}{c}\text { Colony } \\
\text { (number) }\end{array}$ & $\mathrm{N}_{1}$ & $\mathrm{~N}_{2}$ & \multicolumn{2}{c|}{$\begin{array}{c}\text { Percentage growth } \\
\text { observed }\end{array}$} \\
\hline 1 & 6.7 & 11.9 & 80 & 74.5 \\
2 & 12.6 & 17.3 & 37 & 98.6 \\
3 & 17 & 20.5 & 20.3 & 105.6 \\
4 & 17.3 & 8.1 & -62.4 & 105.6 \\
5 & 18.4 & 15.8 & -14.04 & 104.2 \\
$6^{*}$ & 25 & 29 & 10.2 & 19.06 \\
7 & 37.8 & 41.5 & 9.6 & 84.5 \\
8 & 40 & 40 & 0 & 55.7 \\
$9^{*}$ & 51 & 62.8 & 14.9 & 61 \\
$10^{*}$ & 77 & 95 & 15.2 & 61 \\
\hline
\end{tabular}

Not every fan exhibited definite responses. Three colonies (1, 2, 3 in Table 2) which had been turned from horizontal to vertical, and one (10, Table 2) turned from vertical to horizontal react most distinctly. In this biotope, current velocities varied from 0 to $70 \mathrm{~cm} / \mathrm{sec}$. Two colonies $(4,5$ in Table 2 ) grew from the 5 th to the 9 th month in the above described manner, after the 9 th month they lost the new growth and some of their old branches. Since current velocities never exceeded $30 \mathrm{~cm} / \mathrm{sec}$, it is possible that these colonies lost their branches at times of little water movement, as in May and June, when their position was too disadvantageous for them. Some colonies became partly overgrown by bryozoans. One colony did not respond at all; it only reduced markedly the thickness of its coenendayme.

The rate of growth in experimental fans was compared to the undisturbed colonies of the same size (Table 2). Growth rate, in all cases except one, was lower for experimental colonies.

\section{DISCUSSION}

The stimuli which direct growth in sea fans are provided by water movement. The reaction of the colony depends on force and direction of these movements and also 
on the parts of the colony they act on, e.g. tentacles of polyps or axial skeleton. It is still unclear whether the receptors lie within the polyps or the mesogloea (TITSCHAck 1970). Assuming the latter case, two kinds of effects of bending a branch are possible: (a) shear forces acting on all cells involved, or (b) piezoelectric phenomena in sclerites (WAINWRIGHT \& DMLON 1969) which are supposed to influence growth in the adjoining cells. Piezoelectric phenomena have been demonstrated for a variety of composite skeleton materials (WeLls 1963, Keninedy \& FARRAR 1965, BAR Ker 1965). Compensation bends in old branches following changes in direction of water movement can be explained by these mechanisms. For the direction of new growth, probably more complicated medhanisms, involving nervous and hormonal processes, must be assumed for Eunicella cavolinii and other Mediterranean fan-shaped gorgonians. Fans growing on horizontal substrates in the flowing zone have frequently a concave shape. THEODOR $\&$ Denizot (1965) assume that this results from two or more directions of water flow. During periods of high current velocities I could observe that these fans bend strongly with the current, thus lying parallel and only the ends of the branches project from the plane of orientation and attain direction perpendicular to the flow. Similar behaviour could be observed in the hydroid Lytocarpia myriopbyllum which has also a concave form. Similarly, on dichotomous forms of the genus Aglaophenia, terminal fans project from the general plane of orientation and are positioned perpendicular to the direction of water movement when stronger currents bend the colony to the ground. Laboratory experiments using flowing water and in situ experiments with continuously rotating fans are planned to investigate further the mechanisms determining structural orientation in these organisms.

\section{SUMMARY}

1. In situ studies were performed on orientation of the planes of branching in colonies of the gorgonian Eunicella cavolinii growing in locations of different topography and water movement. Employing frequency analysis, orientation patterns were revealed which demonstrated the influence of water movement on these orientations.

2. The importance of substratum morphology was demonstrated by staining individual water bodies with fluorescein sodium.

3. A typical modification in growth pattern of $E$. cavolinii is characterized, indicating zones of strong whirls and turbulence: the second critical depth (RredL 1964, 1971).

4. The second critical depth can be defined by projected circumscription of fan-top views plotted against depth as well as the flowing zone and oscillation zone. In zones of stable water movement directions, the projected area of fan-top views show only slight variations, expressed by the standard deviations.

5. In situ experiments demonstrate clearly the effect of water movement on growth pattern and fan orientation in $E$. cavolinii. Colonies of various sizes were turned from their natural position perpendicular to the direction of water movement until the fan was parallel to this direction. During structural re-adjustment, the following responses could be noted: (a) Inhibition of growth for the first 5 months; (b) new growth perpendicular to the original fan plane; (c) compensation in 
branches whose tips grew in new directions; (d) occasional loss of the two-dimensional shape under the new conditions of water movement.

6. Growth rate was compared in experimental and undisturbed colonies. Growth rate was in most cases lower in experimental than in undisturbed colonies.

7. The mechanisms of reorientation of $E$. cavolinii under the new conditions of water movement are discussed in the light of comparable responses shown by other organisms.

Acknowledgements. I thank Professor Dr. R. Riedu and my friend Dr. J. OTT for valuable discussions, and my friend A. StEZAK for diving assistance. This investigation was supported by the Bundesministerium für Wissenschaft und Kultur, the Notring der Wissenschaften and the Kulturamt der Stadt Wien.

\section{LITERATURE CITED}

AbEl, E., 1959. Zur Kenntnis der marinen Höhlenfauną unter besonderer Berücksichtigung der Anthozoa. Publ. Staz. zool. Napoli (Suppl.) 30, 1-94.

BARKER, R. M., 1965. Microtextural variation in pelecypod shells. Malacologia 2, 69-86.

KenNedy, R. W. \& Farrar, J. L., 1965. Tracheid development in tilted seedlings. In: Cellular ultrastructure of woody plants. Ed. by W. A. CotÉ. Syracuse Univ. Press, Syracuse, 419-453.

Косн, G., 1887. Die Gorgoniden des Golfes von Neapel. Fauna Flora Golf. Neapel 15, 1-99.

Peres, J. M. \& Picard, J., 1949. Notes sommaires sur le peuplement des grottes sous-marines de la région de Marseille. C. r. somm. Soc. Séanc. Biogéogr. 26 (227), 42-45.

RIEDL, R., 1964. 100 Jahre Litoralgliederung seit Josef Lorenz, neue und vergessene Gesichtspunkte. Int. Revue ges. Hydrobiol. 49, 281-305.

- 1971. Water movement: Animals. In: Marine Ecology. Ed. by O. KinNE, Wiley-Interscience, London 1 (2), 1123-1149.

THEODOR, J., 1963. Contribution à l'étude des Gorgones. III. Trois formes adaptives d'Eunicella stricta en fonction de la turbulence et du courant. Vie Milieu 14, 815-818.

- \& Dentzot, M., 1965. Contribution à l'étude des Gorgones (I). A propos de l'orientation d'organismes marins fixés végétaux et animaux en fonction du courant. Vie Milieu 16, 237-241.

Trrschack, H., 1970. Uber das mesogloeale Nervensystem der Oktokorallen Alcyonium palmatum PaLxas und Eunicella stricta (BerTolonr). Zool. Anz. 185, 68-75.

Watnwright, S. A. \& Dillon, J. R., 1969. On the orientation of sea fans (genus Gorgonia). Biol. Bull. mar. biol. Lab., Woods Hole 136, 130-139.

WELLS, J. W., 1963. Coral growth and geochronometry, Nature, Lond. 197, 948-950.

Author's address: B. VeLimirov

I. Zoologisches Institut Universität Wien

Lehrkanzel für Meeresbiologie

A-1090 Wien

Währingerstr. 17

Austria 